\title{
Mapping of Inbound Flows in Supply Chain of Lithium-ion Industry in Indonesia
}

\author{
Wahyudi Sutopo ${ }^{1,2^{*}}$, Roni Zakaria ${ }^{1}$, Ari Wardayanti ${ }^{1}$, Fakhrina Fahma ${ }^{1,2}$ \\ ${ }^{1}$ Industrial Engineering Department, Faculty of Engineering, Sebelas Maret University, Surakarta, Indonesia \\ ${ }^{2}$ National Center for Sustainable Transportation Technology, Indonesia \\ *Email: wahyudisutopo@staff.uns.ac.id
}

\begin{abstract}
The demand for lithium battery is currently high from the consumer side due to the widespread application of lithiumion battery for electronics (laptops, notebooks, mobile phones, street lighting) and electric vehicles (electric cars and electric motors). In Indonesia, the research and industrialization on lithium-ion battery have been conducted to develop products such as for electric vehicles and street lighting. On the other hand, the relationship between suppliers, producers, distribution channels, and consumers has not been mapped. This mapping is intended to provide an overview of the strength of suppliers, involved manufacturers, and to determine the readiness of the value chain of lithium-ion battery to perform mass production. The approach in the mapping uses primary data and secondary data for the initial stage of inbound flows in supply chain of lithium-ion industry in Indonesia. Primary data are obtained from the questionnaires, which adopted from the value chain lithium-ion battery research in USA adjusted for Indonesian context. Meanwhile, the secondary data derived from literature reviews. The respondents in the study are 11 institutions consisting of manufacturers and R\&D of lithium-ion battery in Indonesia. The results obtained are supplier mapping that provides the flow of lithium-ion battery, cell, module, and pack as well as the producers and consumers. The results could also be utilized to identify the valuable metrics in the supply chain of lithium battery industry.
\end{abstract}

\section{Keywords}

Inbound logistic; Lithium-ion battery; Mapping supply chain; Value chain

\section{Introduction}

Nowadays, the lithium-ion battery is widely used in various applications. The lithium-ion battery has the advantage of the best energy-to-weight ratio [1] and has a relatively low self-discharge when used [2]. A lithium-based battery is capable of storing as much as three times more energy than other materials, thereby providing superior competitiveness and making it the main ingredient for battery manufacturing. The other benefits of lithium-ion battery are high energy density, long life-span, and no memory effect [3]. This battery also has a faster-charging process than NiMH battery and life cycle up to 3000 charging times [4] as well as lighter and smaller when compared to other rechargeable batteries [5].

The consumption of lithium-ion battery has increased significantly in recent years due to widespread use of portable electronic devices, electric vehicles, and grid storage applications [6]. The demand for lithium-ion battery increased up to $38 \%$ from 2013 to 2016 for electronics, e-bikes, electric vehicles and energy storages [7]. In Indonesia, the development of lithiumion battery is currently in the stage of assessment and development for motor vehicles (electric cars) [8] and some other electronic devices such as power bank, smartphones battery, and street lighting. This can be seen from the existence of some government-owned laboratories, universities, and companies that have been conducting the research, development, and manufacture of lithium-ion batteries.

Because the technology of lithium-ion in Indonesia is a new technology, there has been no mapping on the supply chain of lithium-ion until now. Supply chain mapping is useful for mapping relationships between suppliers, producers/manufacturers, distribution channels and consumers. Therefore, this study aims to map the supply chain of lithium-ion battery in Indonesia and to provide an overview of the value chain of lithium-ion battery to perform the mass production.

\section{Literature Review}

\subsection{Supply chain management}

Supply Chain Management (SCM) has been interpreted by various researchers. Based on the recent development of the supply chain literature, it is not surprising that there has been much debate regarding the definition of SCM. Ganeshan and Harrison [9] have defined SCM as a network of facilities and distribution options that performs the functions of materials 
procurement, materials transformation into intermediate and finished products, and the finished product distribution to customers. Lee \& Corey [10] stated that SCM consists of integrated activities taking place among a network of facilities that procure raw material, transform them into intermediate goods and then final products, and deliver products to customers through a distribution system. Christopher [11] defined the supply chain as the network of organizations that are involved, through upstream and downstream linkages, in the different processes and activities that produce value in the form of products and services in the hands of the ultimate customer. Simply stated, "the supply chain encompasses all of those activities associated with moving goods from the raw-materials stage through to the end user" [12].

\subsection{Logistic activities}

Logistics activities consist of inbound and outbound logistic. Inbound logistic refers to the sourcing, expediting, and receiving of goods, that is coming to the business organization. On the other extreme, outbound logistic is all about warehousing, packaging and transporting of goods, going out from the organization.

Inbound logistic is the activities which are related to sourcing, acquiring, storing and delivering the raw materials and parts to the product or service department. It is part and parcel of operations, for a firm involved in manufacturing business. In simple terms, inbound logistic is the fundamental activity, which focuses on buying and scheduling the inflow of materials, tools and final goods, from suppliers to the production unit, warehouse or retail store.

Outbound logistic, as the name suggests, is the collection, storage and distribution of the final goods and related information flows, from the manufacturing plant to the end user. It covers all those activities (i.e. selecting, organizing, transporting, etc.) which are involved in the merchandise outflow from seller to the buyer [13]

\section{$3 \quad$ Methodology}

In this study, the questionnaires are given to 11 institutions consisting of $\mathrm{R} \& \mathrm{D}$ and manufacturing institutions to obtain primary data, while secondary data are obtained from the literature review. R\&D is a party that conduct researches and develops lithium-ion battery while manufacturing is a party that process raw materials, cells, modules or lithium-ion battery packs until the final product. The R\&D institutions are UNS, ITS, UGM, ITB, LIPI, B4T Bandung and BATAN which is denoted by R\&D1 - R\&D7 and the manufactures are UNS spin-off, PT LEN, PT Hikari Solusindo Sukses, PT Nipress, and DSBC which is denoted by Man1 - Man5. The questionnaire is based on the adoption of the lithium-ion battery value chain model in the USA. This mapping consists of supply chain lithium-ion battery from raw materials to lithium battery application products. It also involves the entities in the lithium-ion battery supply chain such as suppliers, manufacturers and R\&D. Therefore, the integration between these entities can be seen. The results of supply chain mapping can provide information on the list of suppliers who supply their products to Indonesia.

Because the lithium-ion battery is a new technology development in Indonesia, there has been no research on the mapping of lithium-ion battery supply chain. Research on the supply chain for lithium-ion batteries has been conducted in the USA [14], Europe [15] as well as other countries [16]. These studies describe the supply chain of lithium-ion battery ranging from raw materials to lithium battery product applications. It also illustrates the entities involved in the lithium-ion battery supply chain such as suppliers, manufacturers and R\&D.

\section{Results and Discussion}

The data were collected by using questionnaires that were distributed to 11 institutions. Questions on the questionnaire were made based on the indicators found in the studies [17] and [18]. The questionnaire design for the mapping can be seen in Table 1.

To illustrate the lithium-ion battery supply chain in Indonesia, the relevance of the system for existing conditions in Indonesia is explained first. Figure 1 is an image of the current relevant system of lithium-ion battery.

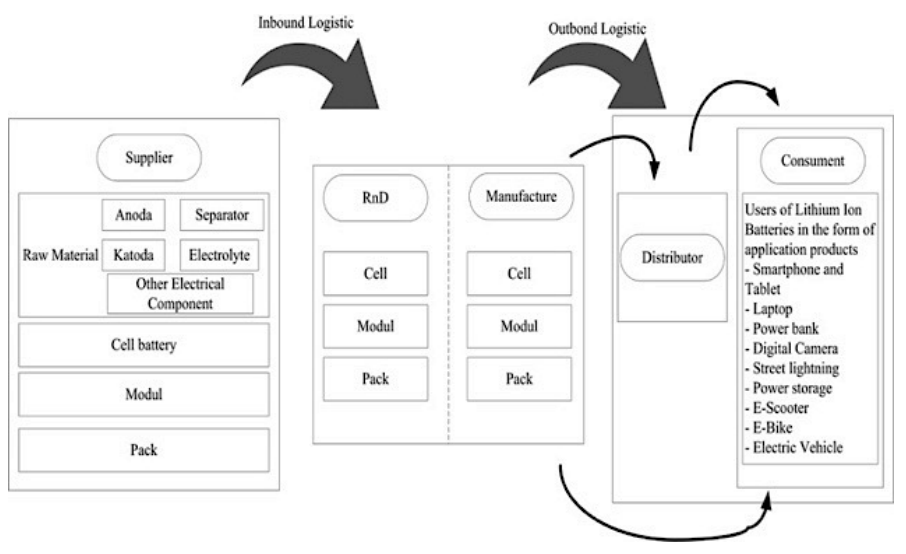

Figure 1 Relevant System of Supply Chain Lithium-ion Battery 
Table 1 Design of Questionnaire [17, 18]

\begin{tabular}{|c|c|c|}
\hline Merit & Criteria & Sub-criteria \\
\hline \multirow{18}{*}{ Benefits } & \multirow{4}{*}{ Quality } & Yield rate \\
\hline & & Product reliability \\
\hline & & Quality of support services \\
\hline & & System quality \\
\hline & \multirow{6}{*}{ Flexibility } & Volume flexibility \\
\hline & & Product mix flexibility \\
\hline & & Customization \\
\hline & & Process flexibility \\
\hline & & Emergency order processing \\
\hline & & Flexibility in services \\
\hline & \multirow{4}{*}{ Delivery } & Order lead time \\
\hline & & On time delivery \\
\hline & & Delivery reliability \\
\hline & & Distribution network quality \\
\hline & & Technological system \\
\hline & Sunplior's Teshnolony & Future technology development \\
\hline & supplier's I echnology & Future manufacturing capabilities \\
\hline & & Cost-reduction capability \\
\hline \multirow{8}{*}{ Opportunities } & \multirow{3}{*}{ Joint Growth } & Acquisition of supplier's knowledge and technology \\
\hline & & Complementary of capability \\
\hline & & Joint product/technology development \\
\hline & \multirow{3}{*}{ Relationship Building } & Stabilized relationship with supplier \\
\hline & & Closeness of relationship \\
\hline & & Ease of communication \\
\hline & & Product price \\
\hline & Cost of Product & Freight cost \\
\hline \multirow[t]{9}{*}{ Costs } & & Extra cost \\
\hline & Cost of relationshin & Cost of forming the relationship \\
\hline & Cost of relationship & Time for forming the relationship \\
\hline & & Supplier's capacity limit \\
\hline & Sunnlier's Constraint & Supplier's capability limit \\
\hline & Supplier's Constraint & Supplier's raw material acquisition difficulties \\
\hline & & Variation in price \\
\hline & Supplier-Buyer's Constraint & Bargaining power of supplier \\
\hline & & Incompatibility between supplier-buyer \\
\hline \multirow{5}{*}{ Risks } & & Financial risk \\
\hline & & Bad performance history and reputation \\
\hline & Supplier's Profile & Inadequate environment controls and programs \\
\hline & & Geographical location \\
\hline & & Packaging ability \\
\hline
\end{tabular}

The lithium-ion battery supply chain system consists of suppliers, lithium-ion battery entities (R\&D and manufacturer), as well as distributors and consumers or users. Supplier provides raw materials to be processed by the R\&D or manufacturer. Products that can be provided by suppliers are raw materials of lithium batteries as well as lithium-ion battery products such as battery cells, battery modules and battery packs. The characteristics of the suppliers also vary, some of them provide only one lithium-ion battery product, while the others are capable of providing some lithium-ion battery products. The parties that process lithium-ion battery from suppliers consist of 2 kinds of institution, namely R\&D which focuses on research and development of lithium-ion battery and its products application, while manufacturer focuses on producing lithium-ion battery as well as for products application to gain profit. Distributor is an intermediary that distributes products from company to consumer. The lithium-ion battery products are then used by consumer in the form of lithium-ion battery products application, such as smartphones, tablets, laptops, power banks, digital cameras, street lighting, power storage, e-scooter, ebike, and electric vehicle. The process of moving products from supplier to R\&D and manufacturer is called inbound logistic while the process of distributing lithium-ion battery from $\mathrm{R} \& \mathrm{D}$ or manufacture to distributor and consumer is called outbound logistic. 
The process of channeling outbound logistic is divided into 2 kinds of sequential process, the first is the distribution of products from $R \& D$ / manufacturer to the distributor then to the consumer, and the second is from the R\&D / manufacturer directly to the consumer.

The result of the questionnaire is the data on the activity of each R\&D and manufacturer related to lithium battery as shown in Table 2. It describes the activities undertaken by $\mathrm{R} \& \mathrm{D}$ and manufacturer including buying raw materials, conducting research and development, and producing lithium-ion battery products. It can also be seen that all R\&D and manufacturer buy materials (do not make their material) and on average have 3 years of experiences for R\&D while manufacturers have 4 years of experiences. There is an $R \& D$ which started to conduct research and development of active cathode material, 3 R\&Ds which develop lithium-ion cell battery, and 3 R\&Ds which develop lithium-ion battery in module form. For lithium-ion battery manufacturer, the companies produce different form of lithium-ion battery products with each company focuses on one kind of form such as, (1) cells, (2) modules, (3) packs, (4) modules and packs, and (5) cells, modules and packs.

The mapping results of the inbound logistic of lithiumion supplier can be seen in Table 3. It shows the list of suppliers and consumers of lithium-ion battery products in Indonesia. Raw material lithium-ion suppliers are Linyi Gelon, Xiamen Tob, Targray, and Celgard. Other suppliers of lithium-ion cell batteries are Sunhokey, Samsung, Sanyo, Lyno, UFO and Panasonic. The suppliers of lithium-ion module and pack batteries are Thunder Sky Winston, CALB and Sinopoly. There are also R\&D and manufacturers who are consumers. Figure 2 shows an image of the lithium-ion battery supply chain by sorting entities which are involved as the supplier of raw material, lithium-ion cell batteries, modules and packs.

To connect with consumers, the majority of supplier use communication media such as email, website, fax and telephone. Various communication media will make it easier for consumers to connect with suppliers. In addition, the payment media owned by the majority of suppliers are T/ T, Paypal and direct transfer. The existence of several options provides benefits for consumers to choose the most appropriate payment method with the company. For product delivery, the method that is frequently used are FOB (Freight on Board), CIF (Cost, Insurance and Freight), and CFR (Cost and Freight). These three methods of delivery have almost the same characteristics in which the seller is responsible for carrying the goods to the port, and the buyer is responsible for loading the goods onto the ship for shipment.

Table 2 Activity in each institution

\begin{tabular}{|c|c|c|c|c|c|c|c|}
\hline & Institution & $\begin{array}{c}\text { Experience } \\
\text { (years) }\end{array}$ & $\begin{array}{c}\text { Raw material } \\
\text { purchase }\end{array}$ & $\begin{array}{c}\text { Material } \\
\text { development }\end{array}$ & $\begin{array}{c}\text { Cell } \\
\text { development }\end{array}$ & $\begin{array}{c}\text { Module } \\
\text { development }\end{array}$ & $\begin{array}{c}\text { Pack } \\
\text { development }\end{array}$ \\
\hline \multirow{8}{*}{$R \& D$} & R\&D1 & 3 & $\sqrt{ }$ & \multirow{7}{*}{$\sqrt{ }$} & $\sqrt{ }$ (cylinder) & & \\
\hline & $\mathrm{R} \& \mathrm{D} 2$ & 4 & $\sqrt{ }$ & & & $\sqrt{ }$ & \\
\hline & R\&D3 & 2 & $\sqrt{ }$ & & & $\sqrt{ }$ & \\
\hline & R\&D4 & 2 & $\sqrt{ }$ & & & $\sqrt{ }$ & \\
\hline & R\&D5 & 3 & $\sqrt{ }$ & & & & \\
\hline & R\&D6 & 2 & $\sqrt{ }$ & & $\begin{array}{l}\sqrt{ } \text { (cylinder, } \\
\text { pouch })\end{array}$ & & \\
\hline & $\mathrm{R} \& \mathrm{D} 7$ & 3 & $\sqrt{ }$ & & $\sqrt{ }$ (cylinder) & & \\
\hline & Institution & $\begin{array}{c}\text { Experience } \\
\text { (years) }\end{array}$ & $\begin{array}{c}\text { Raw material } \\
\text { purchase }\end{array}$ & $\begin{array}{c}\text { Raw material } \\
\text { production }\end{array}$ & $\begin{array}{c}\text { Cell } \\
\text { production }\end{array}$ & $\begin{array}{c}\text { Module } \\
\text { production }\end{array}$ & $\begin{array}{c}\text { Pack } \\
\text { production }\end{array}$ \\
\hline \multirow{5}{*}{ Manufacturer } & Man1 & 3 & $\sqrt{ }$ & & $\sqrt{ }$ (cylinder) & & \multirow{3}{*}{$\sqrt{ }$} \\
\hline & Man2 & 3 & $\sqrt{ }$ & & & & \\
\hline & Man3 & 2 & $\sqrt{ }$ & & & $\sqrt{ }$ & \\
\hline & Man4 & 5 & $\sqrt{ }$ & & & $\sqrt{ }$ & $\sqrt{ }$ \\
\hline & Man5 & 4 & $\sqrt{ }$ & & $\sqrt{ }($ pouch $)$ & $\sqrt{ }$ & $\sqrt{ }$ \\
\hline
\end{tabular}


Table 3 Lithium-ion supplier in Indonesia

\begin{tabular}{|c|c|c|c|c|c|c|c|c|c|c|}
\hline Supplier & Cathode & Anode & Separator & Electrolyte & $\begin{array}{c}\text { Another } \\
\text { Component }\end{array}$ & Cell & Module & Pack & Country & Consumer \\
\hline $\begin{array}{c}\text { Linyi } \\
\text { Gelon Ltd. }\end{array}$ & $\sqrt{ }$ & $\sqrt{ }$ & $\sqrt{ }$ & $\sqrt{ }$ & $\sqrt{ }$ & & & & China & $\begin{array}{c}\text { Spin-off } \\
\text { UNS, B4T } \\
\text { Bandung, } \\
\text { LIPI, DSBC }\end{array}$ \\
\hline $\begin{array}{c}\text { Xiamen } \\
\text { Tob }\end{array}$ & $\begin{array}{c}\sqrt{ } \text { (Active } \\
\text { Material \& } \\
\text { Carbon) }\end{array}$ & $\begin{array}{c}\sqrt{ } \\
\text { (Carbon) }\end{array}$ & & $\sqrt{ }$ & $\sqrt{ }$ & & & & China & B4T Bandung \\
\hline Targray & $\begin{array}{c}\sqrt{ } \\
\text { (PVDF \& } \\
\text { Al Foil) }\end{array}$ & $\begin{array}{c}\sqrt{ } \text { (Active } \\
\text { Material, } \\
\text { Binder \& } \\
\text { Al Foil) }\end{array}$ & & & & & & & Canada & B4T Bandung \\
\hline Celgard & & & $\sqrt{ }$ & & & & & & USA & B4T Bandung \\
\hline Sunhokey & & & & & & $\sqrt{ }$ & & & China & $\begin{array}{c}\text { ITS } \\
\text { UGM, PT }\end{array}$ \\
\hline Samsung & & & & & & $\sqrt{ }$ & & & $\begin{array}{l}\text { South } \\
\text { Korea }\end{array}$ & $\begin{array}{c}\text { Hikari } \\
\text { Solusiondo } \\
\text { Sukses }\end{array}$ \\
\hline Sanyo & & & & & & $\sqrt{ }$ & & & Japan & B4T Bandung \\
\hline Lyno & & & & & & $\sqrt{ }$ & & & Taiwan & $\begin{array}{l}\text { ITB, PT } \\
\text { Nipress }\end{array}$ \\
\hline UFO & & & & & & $\sqrt{ }$ & & & China & $\begin{array}{l}\text { ITB, PT } \\
\text { Nipress }\end{array}$ \\
\hline $\begin{array}{l}\text { Panasonic } \\
\text { Thunder }\end{array}$ & & & & & & $\sqrt{ }$ & & & Japan & ITS \\
\hline $\begin{array}{c}\text { Sky } \\
\text { Winston }\end{array}$ & & & & & & & $\sqrt{ }$ & $\sqrt{ }$ & China & PT LEN \\
\hline CALB & & & & & & & $\sqrt{ }$ & $\sqrt{ }$ & China & PT LEN \\
\hline Sinopoly & & & & & & & $\sqrt{ }$ & $\sqrt{ }$ & China & PT LEN \\
\hline
\end{tabular}

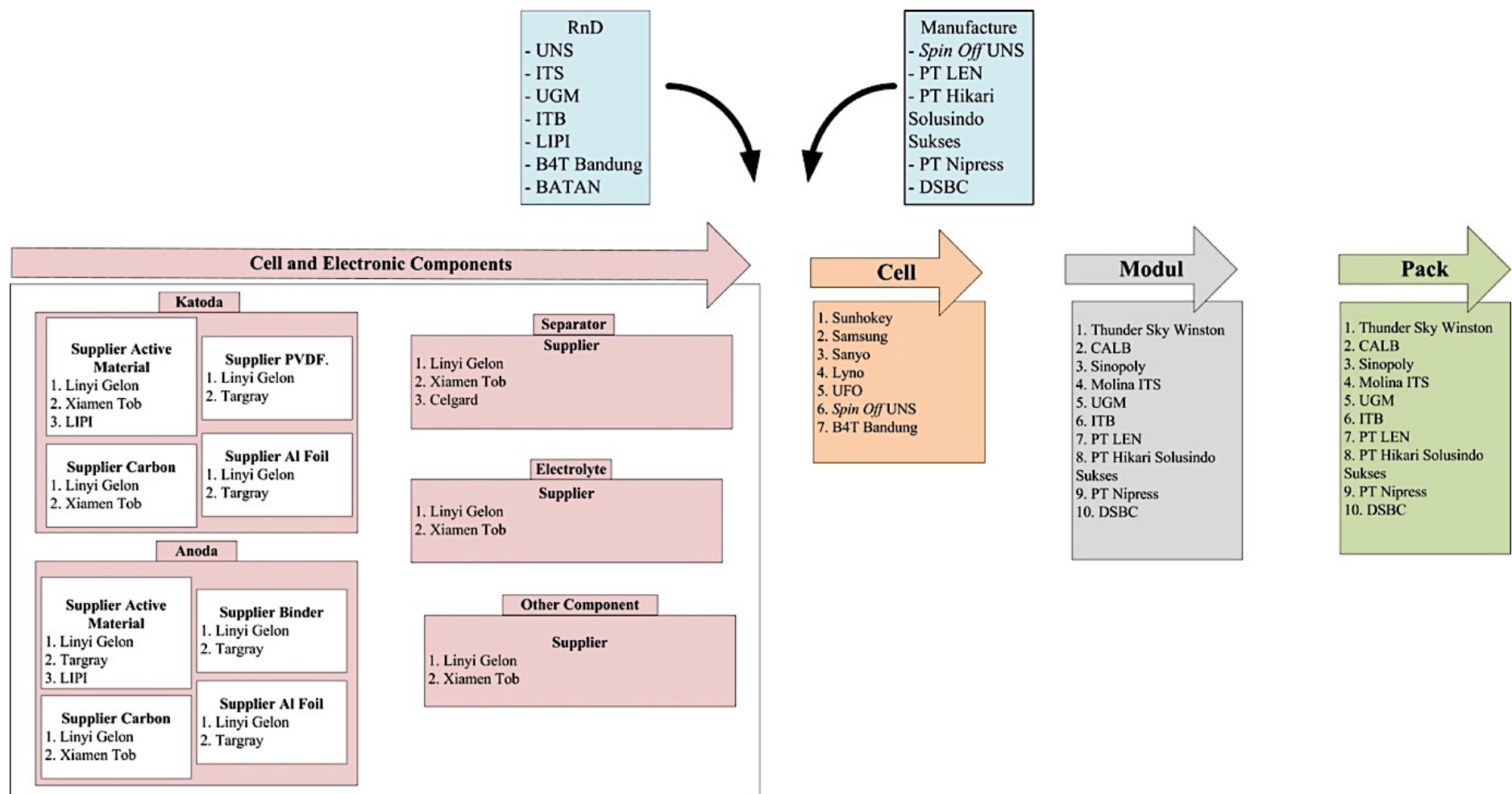

Figure 2 Lithium-ion battery supply chain (inbound logistics) 
The majority of suppliers who supply lithium-ion batteries to Indonesia are suppliers coming from China because China is the largest producer of lithium. The Chinese suppliers that supply most of raw materials demand of R\&D and manufacturer is Linyi Gelon Ltd. Linyi Gelon Ltd. is a retail company that provides raw materials for lithium-ion batteries (cathode, anode, separator, electrolyte and other components). Linyi Gelon Ltd. becomes a major supplier because this supplier has a distribution point in Jakarta, Indonesia which is called PT KGC. This company facilitates the buyer in getting the product. Another distributor of lithium-ion in Indonesia is PT Kalimas. This distributor usually distributes materials of lithium-ion battery from supplier in China to $R \& D$ and manufacturer in Indonesia

\section{Conclusion}

The relevant supply chain system of lithium-ion battery in Indonesia consists of suppliers, processing parties (R\&D and manufacturer), distributors, and consumers. The focus of each R\&D and manufacturer activities are different. The activities for $R \& D$ institution include raw materials purchase, and raw material, cell, modules and packs research. The activities for manufacturer include lithium-ion battery production in the form of cells, modules and packs. Based on the mapping results, it is known that the supply of lithium-ion batteries to Indonesia is dominated by China, although there are other suppliers from Canada, Japan, South Korea, and USA.

\section{Acknowledgement}

This paper is supported by USAID through Sustainable Higher Education Research Alliances (SHERA) Program - Centre for Collaborative (CCR) National Center for Sustainable Transportation Technology (NCSTT) with grant no. IIE00000078-ITB-1.

\section{References}

[1] Nipress, The explanation from Research and Development department of PT Nipress Tbk, Bogor, 2015.
[2] Sumiati and T. Sugiharto, "Studi kelayakan proyek pengembangan perkebunan pisang Abaca dengan menggunakan analisis peranggaran modal", Jurnal Eknomi dan Bisnis, vol. 7, pp. 145 - 150, 2002.

[3] F. Davies, "The lithium market", 2013.

[4] W. Sutopo, N. A. Atikah, A. Purwanto, and M. Nizam, "The battery $10 \mathrm{kWh}$ : A financial analysis of mini manufacturing plant" in Joint International Conference on Rural Information \& Communication Technology \& Electric-Vehicle Technology, 2013.

[5] W. Sutopo, D. M. Indah, A. Purwanto, and M. Nizam, "A comparative value chain analysis of battery technologies for electric vehicle," In Joint International Conference on Rural Information \& Communication Technology \& ElectricVehicle Technology. 2013.

[6] National Minerals Information Center, Mineral Commodity Summaries, 2012.

[7] H. K. Mathew, J. P. Young, P. Terry, and D. Begleiter, "Lithium industry report," Sydney: Deutsche Bank, 2016.

[8] Badan Pengkajian dan Penerapan Teknologi, Kajian Roadmap Pengembangan Energy Storage Untuk Smart Grid System, Pusat Teknologi Konversi dan Konservasi Teknologi, 2013.

[9] R. Ganeshan and T. P. Harrison, An Introduction to Supply Chain Management, Department of Management Sciences and Information Systems, 1995.

[10] H. L. Lee and C. Billington, "The Evolution of supply-chainmanagement models and practice at Hewlett-Packard interfaces," Interfaces, vol. 25, pp. 42-63, 1995.

[11] Christopher M., Logistics \& supply chain management: strategies for reducing costs and improving services, London: Pitman Publishing, 1998.

[12] S. Zigiaris, Supply chain management report for the EC funded project by BPR Hellas SA, 2000.

[13] S. Surbhy, "Difference between inbound and outbound logistics," in http://keydifferences.com/difference-betweeninbound-and-outbound-logistics.html, 2017. [accessed on September 15, 2017]

[14] M. Lowe, S. Tokuoka, T. Trigg, and G. Gereffi, "Lithum-Ion batteries for electric vehicle: The U.S value chain," from https://unstats.un.org/unsd/trade/s geneva2011/refdocs/RDs/ Lithium-Ion\%20Batteries\%20(Gereffi\%20\%20May\%202010).pdf, 2010. [accessed on September 15, 2017]

[15] Lebedeva, N, Franco D. P. and L. Boon-Brett, "Lithium-ion battery value chain and related opportunities for Europe," from http://ec.europa.eu/jrc, 2016. [accessed on September 7, 2017]

[16] Mathew, Hocking, J. Kan, P. Young, C. Terry, and D. Begleiter, Lithium Industry Report, Deutsche Bank, 2016.

[17] A. H. I. Lee, "A fuzzy supplier selection model with the consideration of benefits, opportunities, costs and risks," Expert System with Applications, vol. 36, pp. 2879-2893, 2009.

[18] G. W. Dickson, "An analysis of vendor selection system and decision," Journal of Purchasing, vol. 2, pp. 5-17, 1966. 